\title{
Învățătură pentru ferirea și doftoria boalelor (1816). Notes on glosses
}

\author{
Liliana Soare* \\ Faculty of Letters, University of Pitești, Str. Gh. Doja 41, 110253 Pitești, Romania
}

\author{
Article info \\ History: \\ Received April 11, 2014 \\ Accepted May 26, 2014 \\ Published January 13, 2015 \\ Key words: \\ glosses \\ lexical borrowings integration \\ modernization of Romanian \\ literary language
}

\begin{abstract}
The aim of the present paper is the minute analysis of glosses excerpted from Invățătură pentru ferirea și doftoria boalelor, a text translated by Petru Maior and printed in Buda, in 1816. The Enlightenment principle followed by the Transylvanian scholar, i.e. the principle of adapting the Western culture to the Romanian one, of facilitating the access of popular masses to science is materialised in the high frequency of glosses. For P. Maior, the gloss represents an excellent mechanism of inserting neologisms in his text, neologisms which are explained by old, popular terms, collocations or periphrases. The highest weight is held by terminological glosses of the lexical borrowing - old term type. The fact is relevant for the conception that guides the author in his activity of translating the text: the glosses are intentionally oriented towards the creating of a neologic lexical corpus, in accordance with that of other European languages of culture. A detailed analysis of the various types of glosses offers useful information as regards the phenomenon of integrating neologisms and reveals interesting aspects of the process of lexical renewal of the Romanian literary language.
\end{abstract}

\section{Introduction}

1.1. Petru Maior conducts an impressive activity of writing, translating and adapting numerous texts in various fields; his editorial activity displays a work organised on almost all fields of the Romanian Enlightenment, work which stakes the most important areas of the written culture of the period. As a censor of the Buda printing house, he receives, among other duties required by his position, the task of translating several texts of science popularization which he does not sign as a translator. Based on convincing linguistic arguments, Ursu (1961) concludes that this text of veterinary medicine, entitled Invățătură pentru ferirea și doftoria boalelor celor ce se încing prin țeară și a celor ce se leagă și a unor boale sporadice, adecă pe ici pe colo îmblătoare, ale vitelor celor cu coarne, precum și a cailor, a oilor și a porcilor (130 pages), published in Buda in 1816, is a translation belonging to Petru Maior ${ }^{1}$.

1.2. Most of the science popularization texts which appear in Transylvania at the end of the $18^{\text {th }}$ century and the beginning of the $19^{\text {th }}$ century are translations and adaptations of Latin, German or Hungarian texts, utilitarian papers belonging to the state, official literature, with a broad circulation in the entire cultural space of the empire. Their translation was a task of the Buda printing house to be carried with the help of the censors of Romanian books. Like the Romanian printing house in Wien or Lwow, the printing house in Buda was obliged, due to the coordinates of the cultural policy of the Austrian Empire, to print textbooks and texts of science popularization for the Romanians in Transylvania. Their goals are varied, a fact which pinpoints the intention of mass culturalization, by passing from an erudite literature to one oriented towards the stringent needs of the community. Many of them are "învățături" (instructions), which show their destination from their titles: Invățătură pentru ferirea și doftoria boalelor, Invățătură pentru prăsirea pomilor, Învățătură despre cultura și creșterea frăgarilor, Invățătură de a face sirup și zăhar,

*Email address: lilianasoare2006@yahoo.com.

${ }^{1}$ For other translations of the Transylvanian scholar, see Ursu (2012). 
Invățătură firească spre surparea superștiției norodului etc., others "povățuiri” (exhortations): Povățuire cătră economia de cîmp, Povățuirea cu praxis cătră sporirea stupilor etc., texts with an obvious pedagogical orientation.

The massive assimilation of foreign texts "dezvăluie, incontestabil, un proces de înnoire a unei scheme culturale și o mai bună înțelegere a acestuia presupune, în primul rînd, integrarea activității de traducere în ansamblul dezvoltării culturii scrise și, în al doilea rînd, investigarea literaturii ca formă de expresie a structurilor mentale din societatea română" (Duţu, 1970, p. 155). The activity of translating and adapting foreign works implies not only the synchronization of Romanian culture and literature with the Western one, but also the assimilation of a new mentality towards man, which is materialised in an accessibile literature. The translations of the period are based on a profound change of mentality structures and on a mutation among scholars, who are much open to a utilitarian mass literature which was to be introduced in a much broader circuit.

As it was observed (Prodan, 1964, p. 5), in this period translation does not represent a facile transposition of familiar notions in an already constituted scientific language. Translation is creation in itself, raising more difficult problems than the original writing in a language familiar to the writer. In the period when the Transylvanian scholars run their activity, individuality and originality did not represent pertinent features in defining a scientific work. They change, recreate, edit the texts they translate; they introduce annotations, eliminate information, replace the examples with other which are familiar to the Romanian reader, connect fragments from various sources, write prefaces etc.

Thus, in the case of official books, elaborated for all the peoples of the empire, the translators do not adapt the text but, as a rule, they closely follow the original. The accuracy of the language of translation is important, but equally important is the authors' endeavour to respect the nature of the Romanian language. Maior (1813), for example, condemns the artificial accuracy of the language in which the translation is being made, saying that: "Grecii așa vreu, ca cărțile cele besericești [...], cînd se întorc pre altă limbă, așa să se întoarcă, cît nu numai înțălesul cel cuprins în cărțile acele să se țină, ci și țesetura cea din lontru a limbei grecești” (p. 182). Consequently, the scholar pleads both for conserving the accuracy of ideas and the meanings of words and the maintaining the specificity of the Romanian language: "Românii [...] cărțile cele besericești le-au întors pre românie după firea limbei românești, numai de aceea grijindu-se ca înțălesul să rămînă întreg” (p. 183). Having in mind that the theory of translation was not constituted yet, we can say that his conceptions are rather modern.

1.3. It seems that the text is translated after a Hungarian original, yet unidentified, a fact which makes the confrontation of the two texts impossible. The idea of the Hungarian original is sustained by the fact that, in two cases, there appear the expressions "iubita noastră patrie Ungaria" ("our beloved country, Hungary") and "patria noastră Ungaria" ("our country, Hungary"): "Întră toate lîngorile sau boalele cornutelor adecă vitelor celor cu coarne, foarte adeseori, cu nenorocita și prea contăgioasa boala de vite sau puștla cornutelor, iubita noastră patrie Ungaria se devastă adecă se pustiaște, cît însuşi cei mai puternici moștenitori ale largilor moșii nevindecate pagube pentru pierderea vitelor sale sînt strimtorați a simți, iară țăreanii ce sînt supuși dărei nu arareori la cea de pre urmă lipsă ajung” (22-23); "Iară cum că boala de vite în patria noastră Ungaria adeseori se escază (și se escază pentru locurile țărei pe ici, pe colo apuse, aşezate, pentru unele locuri băltoase, pentru desele vărsări de ape, pentru răsfugările pămîntului cele cu putrăgiune, pentru notrețul cel stricat, pentru aerul cel nesănătos, pentru apele cele tăioase), care toate, afară de contagiu, cum că singure de sine pot să nască această pierzătoare boală, netăgăduit lucru iaste” (25). In another place, Moldavia and Wallachia are referred to as "țări streine” (“foreign countries"): “Întru adevăr, de prisosit iaste acum adeverit, cum că boala cea de vite și în țeara noastră mai adeseori se urzește: totuș, cum că acest stricătoriu rău mai vîrtos din țări streine, precum Moldova, T,eara Românească, Rusia se lățește la noi, dovedit iaste” $(28-29)^{2}$.

\footnotetext{
${ }^{2}$ These fragments are supplementary proof that Petru Maior closely follows the original: the Hungarian author writes about "patria noastră Ungaria", and the remarks to the other two Romanian provinces as foreign countries are made from outside.
} 
1.4. As Ursu (1962, p. 61) observed, this is our first medical text in which we can find a much richer speciality terminology with an obvious neologic character. However, what strikes us, besides the high weight of lexical borrowings ${ }^{3}$, is the high frequency of glosses (the title itself contains such an explanatory terminological structure: boale sporadice adecă pe ici pe colo imblătoare). The neologic terms are explained every time they are used, the cases in which they appear, subsequently to their first glossing without being included in the same or other explanatory structure are rare. An ordinary page of the book looks like in the following examples: "Aftele sau răniturile limbei trăbuie să se socotească numai ca simptome adecă schimbări fără cumpăt sau depunerea, descărcarea materiei ceii morboasă adecă a morbului sau a boalei la zisele părți; pentru aceea periclu sau rișchiu adecă primejdia boalei depende (atîrnă) de la forța adecă puterea ziselor friguri" (74); "Grumăzarea sau angina sau brînca porcilor iaste epidemică adecă se încinge și e foarte fatală sau stricătoare boală” (81).

Faced with new (scientific) concepts, the scholar is forced to appeal to explanation mechanisms in order to facilitate their understanding and assimilation. Scientific vulgarization, which has as a main objective the adaptation of the scientific text in order to be understood by the ordinary readers is combined with lexical vulgarization, which takes into account the cultural profile of the readers; the information is therefore formulated in the reader's linguistic systems of representation. Consequently, at the end of the book, perfectly aware of the fact that, in order to be understood, the new knowledge should be translated into the reader's idiolect, P. Maior warns and guides him in his journey to the edification of the book meaning: "Cinstite cetitoriule! Vei afla unele cuvinte în cărticica aceasta, care, poate cu văzuta dintîiu, nu le vei pricepe; ci să nu te scăndălizești! [...] Deci să binevoiești a ceti și a prociti toată cărticica, că toate acele cuvinte, care ți se părea streine, au într-un loc, au într-altul, au încă mai de multe ori le vei afla cu cuvinte de ale patriei tale tălmăcite și la dezvălită înțelegere aduse” (127, emphasis added).

Though impressive, this obsession of accessibility burdens the text and bears on the cursivity of the sentence: "Semne de moarte sînt pulsu sau mișcarea, baterea sîngelui mai nepriceput, cu atîta celeritate (pripire, iuțeală) zbucnește, cît aproape la o sută, ci cu oscuritate, adecă întunecat, se numără, respirația sau răsuflarea e scurtă, sufocativă, adecă sugrumătoare, apetita prostrată sau depusă, pierdută, aversația, adecă urîrea apei; unde ocură (vin, se ivesc, se văd) aceste semne, nu va trăi animantul o jumătate de zi, iară acele adeverit amuș vor subsi, a cărora urechile și astremitatele acum le sînt răci, cărora, de li băga degetele în urechi, nici capu nu-şi mişcă” (63-64).

1.5. As a linguistic means which consists in establishing an equivalence relation between two terms (lexemes or collocations) or in explaining, through periphrases, certain terms, the lexical glossing can be traced back to our first literary texts elaborated in the $16^{\text {th }}$ century. The glossing phenomenon manifests itself with an extraordinary force and with a well-determined aim at the end of the 18th century and the beginning of the $19^{\text {th }}$ century, when modern literary Romanian was constituted and when the problem of creating the scientific terminology and disseminating it among the masses was stringently raised. The gloss provides the accuracy and the denotative function of the scientific terminology. At the same time, this linguistic device is relevant for the intention of making the new terms more accessible as well as for the relation between the cult, erudite terminology and the old one, being relevant for the lexical and semantic adaptation of neologisms. Thus, the glosses represent an important factor in the process of penetration and circulation of neologisms, preparing the semantic and styllistic field for the renewing of the literary language.

The speciality literature records many studies on glosses in the old Romanian texts ${ }^{4}$. Unlike other

\footnotetext{
${ }^{3}$ We intend to dedicate a special study to the lexical borrowings used in the text; after a quick consulting of our main lexicographical works, we observed that many of the neologisms which, probably, have their first attestation in this book are subsequently attested or are not recorded at all.

${ }^{4}$ Among these, we mention only some: Gh. S,incai. Opere, vol. 1, București, 1967, edition (in four volumes) realised by F. Fugariu, who, in the introductory study, excerpts and analyses a rich material of glosses (p. CLXXIX-CLXXXVII); G. Țepelea, Studii de istorie și limbă literară, București, 1970 (p. 13-51); Al. Niculescu, Premesse sul problema dei rapporti cultural-linguistici italo-romeni, in "Actele celui de-al XII-lea Congres internațional de lingvistică și filologie romanică", II, 1971,
} 
researchers who tackled with the problem, Al. Gafton regards the device as an organic component of the translation activity, as an issue creator of literary norm; therefore, the author examines the glosses from our old (religious) texts from the perspective of the needs that have generated them and the functions they fulfil. Gafton (2012) also proposes a basic typology of glosses, writing about explanatory, completive and orientative glosses. Many of them, the author shows, can sum up the features of all types of glosses, therefore a more rigurous classification is almost impossible (p. 323-358).

\section{The inventory of glosses}

Most of the glosses found in the examined text, Invățăturii pentru ferirea și doftoria boalelor, can be explained through the pauperity of the Romanian of the period, which did not have the necessary terms in order to denominate the new realities. The most numerous ones are those which explain the new terms, unknown or little known to the reader, with the help of old, popular terms.

2.1. From a graphic point of view, the glosses are included in the text. However, there are 13 cases in which the glosses are placed as a foot note, with a reference mark. This type of gloss is relevant for the beginning of development of the critical apparatus, for the scientific elaboration of texts following specific norms:

- Despre ferirea boalei vitelor, g. „Vită iaste orice are sîmţire și răsuflare. Deci cu acest nume numim preste tot boii, caii, oile, caprele, porcii ș.c. Și la latini au trăbuit mai demult aceste să se cheame vite; şi de acolo au rămas la latini cuvîntul veterinaria (v e t e r i n a r i a), adecă măiestria de a doftori vitele. Vita se zice românește și viețuitoriu, ba și animant și animal, care nume se cuvine și omului, numai că omul iaste animal cuvîntătoriu, iară vita e animal necuvîntătoriu." (3);

- notreț, g. „Notrețiaste fînul, paiele, ovesul și orice cu care se hrănesc vitele. Cuvîntul acest iaste născut de la vorba latinească nutrio (n u t r i o), care va să zică „hrănesc”. De acolo zicem nutremînt, carea aceea înseamnă ce și cuvîntul, notreț: nutresc, carea una e cu hrănesc." (3);

- poiețile sau staurile, g. „Sălașelor, unde se ține închise și se hrănesc vitele, pre alocurea după feliurile vitelor desclinite nume s-au obicinuit a se da, așa: sălașul unde se țin vitele cele cu coarne, adecă boii, vacile, îl cheamă poiată, unde caii, grajd, unde oile, staur, unde porcii, coteț sau cocină ș.c. Noi a tuturor vitelor, ori de ce plasă să fie, sălașul îl chemăm în cartea acesta staur, că și latinii toate acestea le numesc stabula, de unde vine și cuvîntul românesc, staur.” (4);

- comunitatelor, g. „Comunitate se zic toți oamenii laolaltă socotiți, cîți sînt în sat sau la oraș. Uneori comunitatea cea mare se împarte în mai multe parțiale sau mai mici comunități. Așa, în Peșta iaste comunitatea românilor, comunitatea grecilor, comunitatea sîrbilor ș.c." (5);

- copia, g. „Vitele toate laolaltă ce sînt supt căștiga, adecă grija păstoriului, unii după plasa vitelor le dau desclinite numiri; aşa, zic turmă de oi, iară turmă de boi nu zic. Noi toate le chemăm copia, după datina românilor celor preste Dunăre, care cuvînt în sine înseamnă mulțime." $(6)^{5}$;

- contagiu, g. „Contagiu se zice acel feliu de boală de carea, numai de se va atinge cel cu această boală de cel sănătos, cel sănătos încă se împle sau boala carea cu atingerea se leagă de altul, cum e vărsatu, rîia s..c. Deci boale contăgioase se zic acele care cu atingerea se leagă de alții.” (11-12);

- lîngori, g. „Lîngoare, pre alocurea, se numește numai un feliu de boală rea, de carea doarme omul dus și, ieșindu-și din fire, vorbește într-aiurea. Ci, fiindcă acest cuvînt în sine înseamnă orice plasă de boală

p. 893-904; Niculescu (1978, p. 148-158); E. Toma, Limbajul științific românesc la începutul epocii moderne (secolele XVIIIXIX), București, 2003 (p. 172-183); L. Soare, Școala Ardeleană. Lexicul scrierilor de popularizare a științei, Pitești, 2012 (p. 168-177).

${ }^{5}$ According to his conception that the literary Romanian should be enriched with borrowings from Aromanian - in the postface of the translation, Maior says: “...întru prefacerea aceștei cărticică m-am întrebuințat cu mai multe dialecte ale limbei românești, din carele unele nu sînt astăzi cunoscute în patria ta...” (127) —, P. Maior uses several words from this dialect: căștiga "grijă" (6), copie "mulțime, turmă" (6), demînda "porunci" (29), puştlă "ciumă, pestă" (22). The influence of the Aromanian dialect is to be seen in the forms with a protetic $a$, as in: acăşună, acrescută, adoi, adoită, amișcată, arîde, aroade, asparge, atoarnă etc., which are to be found in many of his translations. 
la românii cei preste Dunăre, și noi în cărticica aceasta întru acel înțăles îl luăm, adecă pentru orice beteșug; totoș, uneori însămnăm cu el anume boala cea rea." (12);

- epizootice, g. „Epizootică boală iaste carea se întinde și se încinge mai preste mult loc întră vite fără de a se împlea una de alta. Însă sînt unele boale, care, afară de aceea că sînt epizootice, au și contagiul împreunat." (13);

- călbeaza, g. „Călbeaza latinește se cheamă Fasciola hepatica, adecă „fașă de ficat”; Carbasus asemenea la latini e o pînză de in foarte subțire, carbasus, dară nu e departe cu înțălesul de „fașă”, deoarăce și carbasul slujește la înfășare. Pentru aceea mi se pare că cuvîntul nostru călbează e născut din latinescul carbasus, mutînd $r$ în $l$, de nu vei vrea mai bucuros a-l trage de la collabasco, fiindcă vitele care au călbează sînt de căzut, de perit; sau de la calvesco, carea înseamnă „mă pleșugesc”, pentru că turma în care încape călbeaza foarte se pleșugește, adecă se rărește, cît de multe ori nici o oaie nu rămîne în viață din turma aceea." (15-16);

- boala de vite, g. „Precum cuvîntul lîngoare pre alocurea înseamnă numai un feliu de boală rea ce vine pe oameni, aşa cuvintul boală de vite înseamnă acea boală rea ce vine pe vitele cele cu coarne, carea la latini se numește Lues Omasi, adecă boala mațului celui cărnos, și iaste ca o puștlă, adecă ciumă întră cornute. Întru acest înțeles luăm și noi aci cuvîntul acela." (22);

- dosă, g. „Dosa, latinește dosis, e cuvînt doftoresc, carele înseamnă acea măsură de lucruri cîtă se dă deodată ori la om, ori la vită." (47);

- gangrenă, g. „Gangrena e carne moartă carea se naște din rană sau din înflămație (aprindere, obrintitură), căria, de nu-i vei sta în coantră cu timpurie vindecare, se tîrîie mai încolo și tot merge înainte rozînd carnea." (57);

- boala cea mucoasă sau suporința, g. „Suporința se zice de la cuvîntul latinesc suppurațio (s u p p u r a t i o), pentru că materia carea iase în boala aceasta din nările calului iaste în chipul puroiului." (85).

The excepted examples show the complex structures of these explanatory devices, the author often resorting to the means of "gloss within a gloss". This type of glosses offers ample explanations of words as well as etymologic information in order to facilitate the understanding of the new terms. Some of them indicate Maior's linguistic preoccupations, as the lexical field established in the case of glossing poiată, or the situation of călbeazăa, which capitalises, by author's direct implication: pentru aceea mi se pare $c \breve{a}$, on very detailed linguistic explanation made with the goal of guiding the reader and broadening his knowledge horizon. The starting point of these footnote glosses is represented by "un segment de text, pretext pentru ca receptorului să i se furnizeze informații noi, care-i lărgesc orizontul sapiențial și de gîndire" (Gafton, 2012, p. 356). Beyond the "rolul lămuritor și îmbogăţitor", these glosses have the role of "de a atrage cititorul spre text, de a-l instrui și forma în sensul și pe baza textului [...]" (ibidem).

2.2. The glosses which are included in the text are most numerous. They reveal various glossing techniques, by using the parantheses, juxtaposition, the conjunction sau or the explanatory apozeme adecă.

2.2.1. A first type of gloss, the most frequent one, inserts synonyms (lexemes or collocations) from the common lexicon in various structures:

a) binary: se va acerăla (sic!) adecă pripi ,accelera” (125), acrimonia sau ascuţimea (100), acurata (cu de ajuns) (48), cu afte adecă cu beșicuțe (72), aftele sau răniturile limbei (74), vor alăbora adecă vor lucra (44), amputația adecă tăierea (111), angina sau grumăzarea porcilor (82), animal (viețitoriu) (62), antifloghistice adecă asupra fierbințelii (51), ample (largi) (65), apetita adecă voia de a mînca (55), apetita adecă voia de mîncare (69), de argilă adecă de lut (80), aversația, adecă urîrea (63), aversă adecă urește (101), boala cea mucoasă sau suporința (85), cadabru adecă trupul cel mort (45), a cadabrului adecă a trupului celui mort (37), putoarea cea cadăbroasă sau de mortăciune (71), calce (var nestins) (114), castrația adecă jugănirea (111), causa sau pricina (73), cautele adecă feriri (33), cauterisația adecă arsura (111), cauteriu adecă fier ars (51), cauție sau ferire (89), cădabru adecă mortul al ei trup (32), (lipsit de) cerc (roșu), adecă de imprejurare (roșie) (56), cicatrice adecă urmă de rană (121), circulația adecă îmblarea sîngelui (124), circumciderea adecă tăierea împrejur (111), a clăudica adecă a schiopăta „claudica” (92), coloră adecă față (56), comerciul adecă împărtăşirea cu vite (35), să se comită adecă să se 
încredințeze (116), boală complicată adecă îndoită (82), comuna (de obște) păşune (31), (sub pedeapsa) confiscației (contraband) (43), contaminate adecă spurcate (91), de a se contăgi adecă de a se împlea (de la alte oi de această boală) (58), continue adecă necurmate (81), să se continue adecă să nu se curme (84), să o continue adecă să nu o curme (122), contrarii adecă împrotivitoare rînduieli (22), cornute adecă vite cu coarne (18), notrețul corupt adecă stricat (94), coruptul adecă stricatul (62), cremotartariu adecă piatră de vin (67), cristalin adecă ca cristalul (57), cruderă adecă nemilostivă (125), cruderitate adecă tirănie (125), custode (păzitoriu) (39), custodie (pază) (39), damne adecă pagube (110), decoct adecă zeamă fiartă (51, 61, 123), decoctu (zeamă fiartă) (76), să se defalce, adecă să se cosască (9), a se dedura (gilui) 6 (91), deliriul adecă nebunia (84), denudata adecă despoiata piele (99), depende (atîrnă) (74), plămînile depravate adecă stricate (82), depunerea, descărcarea materiei ceii morboasă (74), destinatul adecă rînduitul loc (45), să se dețină adecă să se oprească acasă (66), se devastă adecă se pustiaşte (23), devăgînd, adecă îmblìnd ermii sau pustii pre platei (uliţe) (107), se devide sau se imparte (73,77), a devora adecă a mînca (108), diarea adecă cufurirea (26), diarea adecă cufureala (51), diferență (desclinire) (113), se diferesc (se deosebesc) (55), să nu se dimită (sloboadă) la păşune (66), regulele cele diretive adecă îndreptătoare (21), dirigență (sîrguință) (108), disposiții adecă rînduieli (114), disposiții sau rînduieli (104), disposițiile (rînduielile) (38), distanță (depărtare) (34), diversă sau deosebită (natură) (55), diverse adecă deosebite (19), doftor sau hirurg (119), emeticu tare (leac de borît) (84), epidemică adecă se încinge (81), esculente adecă bucate putrăde „excremente?” (108), esempruri adecă pilde (111), faciritate adecă cu lesnire (87), falsă adecă neadevărată (95), fatală sau stricătoare boală (81), fatalul adecă pierzătoriul (34), fenomene (arătări) (83), fuid adecă curătoriu (117), cu foarcepă adecă cu clește (115), forța adecă puterea (74), cu forța (sila) (39), cu fosă adecă cu groapă încungiurate (41), apă frigidă adecă rece (84), frigidă (rece) (108), funestul adecă perzătoriul rău (105), furfură adecă tărîțe (cu apă stropite) (60), de furfură adecă de tărîțe (fierte) (61), găngrenos adecă rănit (27), generale (pe de asupra) (21), spre generație adecă spre prăsire (95), genuin (adevărat) (96), în gradu adecă în treapta (86), bronice adecă lung vecuitoare (86), infusu sau fiertură (122), înferma adecă bolnava vită (80), înflamația sau aprinderea (77), rane înflămate sau aprinse (72), înflämația sau aprinderea (61), înfus adecă zamă fiartă (69), să se înhume adecă să se ingroape (114, 115), se va înstila adecă picura (54), să se întărzică (oprească) (44), lienita sau boala de splină (62), (cu) lienitidă adecă cu boală de splină (57), litarghiriu adecă de oțet de spumă de argint (79), masă adecă aluat (69), membrana sau pelița (88), moment (cirtă) (125), morbul adecă boala (68), morbu sau boala (81), mordac adecă muşcătoriu (110), moturi (mişcări) (123), munde adecă curate (64), munde adecă curățite (85), murii adecă păreții cei de pietră (53), murii sau păreții cei de pietră (91), necesarie (de trăbuință) (116), necesitatea adecă lipsa (49), necesitați sau strimtorați (108), necorupt adecă nestricat (108), nocib sau vătămători (109), nocibe adecă vătămătoare (107), nocivă adecă vătămătoare (71), partea cea nudă adecă goală (93), nude adecă goale (71, 115), nutremînt (notreț) (50), de nutremînt adecă de hrană (108), nutri adecă hrăni (90), ocasia (prilejul) (111), ocasionale adecă prilegiuitoare (105), oculația adecă altuirea vărsatului (59), operații (lucrări) (110), o oră adecă un ceas (34), cu oscuritate, adecă întunecat (63), a se osărba (a se ținea) (107), se oserbă adecă să ia aminte (101), ostipația adecă încuiarea pîntecelui (66), ostruție adecă încuiere (67), palatul adecă ceriul gurei (72), pastă adecă aluat (80), penuria adecă lipsa (62), peregrinatori (nemernici) (39), în periodul adecă în cursul (87), de precauţie adecă de încungiurare regule (107), predespun adecă gătesc spre această boală (89), preserba adecă scuti (112), preservativ sau scutitoriu asupra pierzătoarei boală (48), mijlociri preservative și curative adecă apărătoare și doftoritoare (21), preservativă sau apărare (48), preservative sau apărări (111), prescriptul sau rînduitul modru (32), prescriptiii (rînduieli) (53), producturile (rodurile) (39), produturi sau lucruri (19), profondă adecă adîncă (63), promove (miscă) (65), impedecarea propagației adecă a lățirei (105), proporționate (potrivite) (65), propria (a sa) (42), proprietari adecă stăpîn (31), să se proveadă adecă să se grijească (38), prudent (cu înțelepție) (95), pruringine adecă mîncătură scărpinătoare (92), prurit adecă mîncătură scărpinătoare (92), prurit adecă mîncare cu

${ }^{6}[. .$.$] "celelalte ale staurului vase de lemn cu muc contaminate adecă spurcate bine se cade a se dedura (gilui), cu dorabla a$ se netezi” [...] (“a gelui”, “a rindela”). 
scărpinare (121), pulsu sau baterea sîngelui (68), răsfugările sau răsufările (pămîntului) (6), să se răpurge adecă să se curăţă $(53,109)$, îi răsistă adecă îi stă în coantră (65), remediu (leac) (112), remediuri (lecuri) (67), loc remotu adecă depărtat (32, 46), repurgația adecă curățirea (52), respirația adecă răsuflarea (63), roborîtoare adecă întăritoare de stomah (de rînză) „,roborant, medicament cu acțiune tonică” (69), mai robuste adecă mai tari (62), sapidă (plăcută) (95), săturat adecă bine fiert „saturat” (84, 85), scabia adecă rîia (94), causa scabiei adecă a rîiei (94), să se scarifacă adecă lin să se străpungă (120), rane scăbioase adecă rîioase (93), schiroasa adecă vîrtoasa îmflătură (86), segregată adecă despărțită de cealelalte (33), segură adecă fără primejdie (112), separată adecă despărțită (31), loc separat sau despărțit (32), servitorii (slujitorii) (44), siguranța (neprimejduirea) (41), simplă (nu lucrată) (60), simptome adecă schimbări färă cumpăt (74), simptomele sau schimbările cele färă cumpăt ale morbului adecă a boalei (68), simptomele sau schimbările cele necumpătate ale boalei (101), spera (nădăjdui) (88), a se spera adecă a se nădăjdui (74), speranță adecă nădejde (83), sperare adecă nădejde (125), speriință sau ispita „experiență” (24, 82), spese sau cheltuiele (89), grija speselor adecă a cheltuielelor (32), spise adecă groase (73), boale sporadice, adecă pe ici pe colo imblătoare (f.t.), cu strie adecă trăsuri sîngerate înveregată (86), subsește adecă moare (45), subsire adecă moarte (50), sudorifere adecă ce fac sudoare (90), sufocativă adecă sugrumătoare (63), supuraţie adecă puroire (78), la supurație adecă la puroire (120), în supurație adecă în puroire (121), apă tepidă adecă călduță (69), terebentină (terpentin) (68), teritoriu (ținut) (114), se termină adecă se sfirș̦este (81), titilație (gîldilitură) „titilomanie” (92), transpirația sau răsuflarea vitei contăgioase (21), trucidarea sau uciderea (41), trucidatei adecă ucisei vită (41), să se trucidă adecă să se junghie (80), să se trucide sau să se impuste (91), să-l trucizi adecă să-l omori (112), trupul cel subsit adecă mort (27), urina adecă udul (63), us adecă întrebuințtare (46), pășunea vaporoasă sau aburoasă (94), mai vegetă sau mai vioaie (68), veterinari adecă doftorii cei de vite (11), veterinari sau doftori de vite (23), veterinaria adecă măiestria de a doftori vitele (3), măiestria veterinariei adecă a doftoriei de vite (48), (în statul) violenției adecă silniciei (110), să se poată voluta (tăvăli) (82), vomitu adecă borîtu (84).

b) ternary: acrimonia sau tăria, asprirea înrăotățită (95), angina sau brînca sau grumăzarea porcilor (15), antifloghistice adecă asupra focului sau a aprinderei (84), atmosfera adecă ținutul sau cuprinsul aerului celui din stauri (53), cadabrul adecă corpul sau trupul cel mort (87), celeritate (pripire, iuțeală) (63), apă comună (de obște, firească) (61), congestii adecă adunături, strinsuri în cap (81), crustă adecă scoarță sau piele de lard (93), regulele dietetice, adecă ale traiului sau a mîncărei şi a beuturei (123), disenteria adecă inima rea, cea putredă (27), disenteria adecă cacăsînge, inima cea rea (51), disposiţie (gătire, întocmire) spre turbare "predispoziție” (66), disposiție sau întocmire, gătire (100), grumăzarea sau angina sau brînca porcilor (81), să încrustezi adecă să ungi sau să alipești îmflatele picioare ale vitei (80), înflămație (aprindere, obrintitură) (57), se vor îngurgita (ghiftui, împlea) (107), îmflătură pendentă adecă atîrnată, spînzurată (82), depunere metastatică adecă amişcată sau petrecută (77), materia morboasă adecă a morbului sau a boalei (74), periclu sau rişchiu adecă primejdia (74),periferia (împrejurul, partea) (37), cuperipneumenia adecă cu răsuflare grea sau aprinderea plămînilor (57), spre preservativă sau apărare, scutire de vărsat (57), preservativă adecă apărare, scutire adeverită (28), primorilor (celor de frunte sau întîi) (29), apetita prostrată sau depusă, pierdută (63), pulsu sau mişcarea, baterea sîngelui (63), să-i rămoavă adecă să-i lipsească de la sine, să-i lapede „a îndepărta” (106), să se repețească adecă să se adoiască, să se poftorească (sărăturile cele slobozitoare) (68), repețita (adoita, poftorita) (60), resoluția adecă desfacerea, descuiarea ostruțiilor adecă a incuierei (67), separată adecă desfácută sau despărțită (80), stimulante adecă întăritoare, aromatice (nutremînturi) (108), terminul adecă capetul sau sfîrșitul boalei (88).

c) quaternary: cautelele adecă luările aminte, apărările, scutirile contagiului (13), îndiferent (lasă-măsă-te-las, nici bun, nici rău, fară ceva mărginire au alegere) (102), melanhonie adecă mîhnire, întristăciune, osteneală a trupului (101), ocură ,apar” (vin, se ivesc, se văd) (64), (chip) preservativ adecă spre apărare, spre ferire, spre scutire (46), o produce sau o naște, o pricinuiaște, o acășună (62), remit adecă îngăduie, se

\footnotetext{
7 “Emanație, evaporare, transpirație”. Cuciureanu (1959, p. 56) explains it by Ital. sfogare (from examples like sfogare la passione), which means “a-și descărca, revărsa patima”.
} 
imblinzesc, alină (68).

d) quintuple: astremitatelor adecă a marginilor sau a capetelor sau a sfirșiturilor sau a lăturilor „extremitate" (63), nutritoare adecă hrănitoare, intremătoare, întăritoare, amărătoare lături de färină (50), să se sugrume (să se impedece, să se oprească, să se curme, să se răteze) (106).

This category also reveals the complexity of the explanatory structures: depunerea, descărcarea materiei ceii morboasă adecă a morbului sau a boalei; devăgînd, adecă îmblînd ermii sau pustii pre platei (uliț); resoluția adecă desfacerea, descuiarea ostruțiilor adecă a încuierei; roborîtoare adecă intăritoare de stomah (de rînză) etc.

This type of glosses represents a privileged instrument of introducing new terms; with the help of sau or adecă, the reader is invited to dissociate between the components of these structures and to construe the next term as an explanation of the first one, the borrowing. The new terms (including the Italienisms and Latinisms representing hapax legomena, such as: cautele, moturi, munde, murii, ocură, rămoavă, răsfugări, remotu, spise, subsire, voluta etc.) are adapted to the phonetic and morphologic system of Romanian and equated with synonyms or collocations familiar to the reader; thus, the phenomenon of glossing has an obvious terminological purpose; these glosses aim at "the terminological transfer" (Niculescu, 1978, p. 150), the relating of erudite terminology to one the reader is familiar with. The goal of the Transylvanian scholar is "extinderea sferei compartimentului lexical românesc, îmbogățirea inventarului lexical, propunînd limbii și vorbitorului neologisme" (Gafton, 2012, p. 334).

2.2.2. Another type of gloss the scholar resorts to is that in which he explains the new terms (much rarely the old one) through a periphrasis; such structures are introduced by adecă, by expressions such as ce/cum se zice/numește/cheamă, (cum) se zice româneşte, care va să zică or parantheses: dosă adecă deodată cîte o lingură (69), mațul duoden adecă cel de doaosprezece degete de lung (27), epidemică adecă carea se incinge mai preste mult loc întră vitele cele cornute (61), cu epidimie (cu încingere mai preste mult loc) (54), Idiopatică se cheamă dacă aprinderea în unghii fară de a fi fost alta mai nainte boală incepe; simptomatică se zice dacă boala de la aprinderea gurei prin depunere metastatică adecă amişcată sau petrecută se naște (77), idrofobia adecă boală carea face a să îngrozi de apă (109), infus adecă băutură ce s-au fiert cu jalie, cu valeriana și cu camfor (52), prin peregrinatori sau nemearnici, adecă prin cei ce îmblă prin țări cu diverse lucruri, negoațe, vestminte de lînă, sau pănură și prin mii alte modruri (21), să se scarifacă adecă cu puțină impunsătură să se pleguiască sau rănească au cu cuțitul să se desfacă (70), (urechile) văcelindu-se adecă într-o parte și într-alta dîndu-se (103), dinții văciliți adecă se mișcă sau, cum se zice, joacă ca mărgeaua „vacilant, mobil” (73), vărsatul cățălat (adecă cînd sgăbunțele sînt boțite, legate laolaltă) (56).

Such glosses have mainly an explanatory and informative role; being interpretative transpositions, they only aim at explaining the terms; the translator is not preoccupied with offering an equivalent terminologic lexeme.

2.2.3. The glosses which insert terms from other languages are rarely used; Latin: aprinderea matului ce se zice „omas” (23), dosa, latinește „dosis” (47), Lues Omasi, adecă boala mațului celui cărnos (22), acid salis (năcreală de sare) (50), infuse (infusa) (67), linsătură de gumi de Arabia (mucilago) (69), matul cel gros ce se zice „omas” (27), mațul ce se zice „abomas” (27), sarea de piatră (sal petre) (65), Italian: arcanu duplicatu (arcano duplicato) (67) or German: läzăret (Roth-Stall) (29).

The presence of the foreign terms can offer precious clues in establishing the etymological source of the Romanian term.

2.2.4. Another category of glosses is represented by the ones which resort to old, popular or regional terms, diachronic, diatopic and diastratic synonyms (Gafton, 2012, p. 351) and in which the author appeals to the linguistic competence of the reader: aborul sau răsuflarea gurei (19), acrescută sau inchegată (85), să se adaugă adecă să se mai mărească dosa (99), a amîna adecă a zăbovi (35), amînare adecă zăbavă (36), amînat (tîrziu) (73), amonim (dojenim) (111), amoniți (dojeniţi) (39), arişchioasă adecă primejdioasă (101), boldul sau patima (de cățălit) (110), rane cancroase adecă lupariță (87), case de oaspeți adecă cricime 
(19), căștiga adecă grija (30), cîrviță adecă pleșugirea (92), se comîndă adecă se întrebuințează (46), copia adecă turma (6), lîna crispă adecă creață (92), se demînde (poroncească) (29), se dezvînă adecă se slăbește (62), a se dimica (a se bate, a se mînca cu alți cîni) (107), doftorie sau vindecare (98), în foabă adecă în groapă (114), cu friguri putrăde adecă cu lîngoare (57), gînfarea sau îmflarea ugerului (63), halec (hering) (120), (picioarele calului) se întumesc adecă se gînfă (87), larmă sau strigare (115), aer liber (slobod) (45, 65), libre adecă ponți (76), pișatul mistreț adecă puțin (63), mortariu (mojar) (99), mulii sau muşcoii (88), noioase adecă grețoase, scîrbelnice (95), op adecă lipsă (10,106), osedite adecă cuprinse (88), osicrat adecă oțet (74), la ospătărie adecă la cricimă (35), la ospătării sau case de oaspeți adecă cricime (91), pleagă (rană) (69), se pleşugește adecă se rărește (16), pricura adecă primejdia (115), în pricură adecă în primejdie (112), mai cu pricură (mai cu primejdie) (64), să se pricure adecă să se primejduiască (113), pricuroasă (primejdioasă) (117), puștlă, adecă ciumă (22), puștlele adecă beșicuțe (55), puștele sau beșicuțe (92), rană sau sgrăbunță (65), rane puturoase, crunte sau, cum se zice, carne vie (78), rişchiu adecă primejdie (104), săponele sau spălături (108), scade adecă se desumflă (78), scăldătoare sau spălarea picioarelor (122), smucide adecă lutoase sau pămînjite (90), stîmpărată adecă călduță (60), stercu (balega) (108), teama sau frica (80), ud sau pișat (19), veglerea adecă privegherea (44), lucrarea vintricelului sau a rînzei (26), păhar de vitru adecă de glajă (54).

Such glosses, based on the resources of the internal lexicon of the Romanian language, can show the terminological scantiness of the text or language or, on the contrary, as Gafton (2012, p. 350-351) shows, they can reveal the fact that the translator achieved the skill to use this device in a far more complex manner: he addresses all Romanians, facilitating them the access to a text written in a certain area of the Daco-Romanian territory and going beyond the regional hall-mark of the lexical material.

2.2.5. In other cases, the author mentions the Latin, Hungarian or German correspondents of the old terms used: Lîngoarea, carea se cheamă „boală de vite”. Latinește, „Lues Omasi”; ungurește, "Marha Dög” sau „Marha Pestis”; nemțește, „Löser Dürre, Magen-Seuche, Pest-Seuche” (13); Värsatu de oi. Latinește, "Variole Ovium”, ungurește, "A'Iuhoknak Himlöje”, nemțește, „Die Blattern bez den Schaafen” (13-14); Boala de gură. Latinește, „Lues Oris”, ungurește „Száj-Fájás, Szájgyuladás”, nemțțște „Maulsenche: MaulEntzündung” (14); Boala de limbă. Latinește, „Aphte Lingua”, ungurește, „Nyelvenek fenefekélye”, nemțește "Zungen Krebs, Zurgen-Schwemme” (14); Boala de picioare sau de unghii. Latineste, "Lues pedum seu ungularum”, ungurește, „Köröm fájás, sántitás”, nemțtește, „Klauen-Seuche” (14); Boala de plämîni. Latinește, „Lues pulmonis”, ungurește, „Tüdögyuladás”, nemțește, „Lungen-Entzündung” (14) etc.

In such glosses, the neologic term does not appear; its absence might be explained by the scholar's cautious atttidude as regards its introduction in the linguistic usage.

2.2.6. A special category of glosses is given by the seven prescriptions elaborated in Latin (containing medicine formulas, quantity of ingredients etc.), which, with the help of adecă, are translated into Romanian: “[...] să se ungă aftele cu următoriul leac: Rc. Pulv. Absynthii rutæ, scordii aa unc. jj. Spiritus salis acidi drach. jj. Mellis com. q.s. Adecă: cu pulbere de pelin, de rută și de scordiu, din toate cîte doao uncii; din lamura sarei acră, drahme - doao și din miare comună cît e de lipsă sau de ajuns, ca să faci dintru aceste pulberi unsoare. De sînt aftele limbei găngrenoase, această unsoare să întrebuințezi: Rc. Pulv. Cascarillæ, salicis gentianæ, aa unc. jj. Camphor, drach. j. Ungventi ægyptiaci, mel rosarum aa q.s. F. Linimentum, adecă: să iai din pulbere de cascarila și de salce gențiana, dintr-amîndoao cîte doao uncii; de camfor, o drahmă, adecă un cheting; de unsoare de Eghipet, precum și de miare de ruje, dintr-amîndoao atîta cît e de lipsă, spre aceea ca, din toate aceste, să faci unsoare și cu aceea să se ungă găngrenoasele afte” (75-76) etc.

\section{Characteristics of glossing the new terms}

Several ways of explaining the new terms by glosses can be identified:

\footnotetext{
${ }^{8}$ Word known in the Transylvanian idioms, with the meaning of "a face comîndul" (pomană, praznic, bunuri adunate pentru înmormîntare).
} 
3.1. The glosses render lexical units which cannot be decomposed: apetita, adecă voia de a mînca (lat. appetitus, germ. Appetit), boale bronice, adecă lung vecuitoare (lat. cronicus, -a, -um), prurit, adecă mîncărime cu scărpinare (lat. pruritus, it. prurito) etc. These translations maintain a semantic relation with the respective borrowings, even though it is not always accurate.

3.2. Glosses render lexical units that can be decomposed in the component parts: (beuturi) antifloghistice, adecă asupra fierbințelei, circumciderea adecă tăierea împrejur, cu epidimie (cu încingere mai preste mult loc), idrofobia adecă boală carea face a să îngrozi de apă, mațul duoden adecă cel de doaosprezece degete de lung, sudorifere adecă ce fac sudoare etc.

3.3. In many cases, the glosses are inaccurate, clumsy, the author using inadequately certain terms (because of the fact that the lexical borrowings did not have coverage in the internal lexicon); it is manifested, to a greater or a smaller degree, the losing of the semantic relation, by the various explanation, more or less approximately, of the meaning of the new terms ${ }^{9}$ : acrimonia sau ascuțimea, acurata (cu de ajuns); aftele sau răniturile limbei; să se comită adecă să se incredințeze; (sub pedeapsa) confiscației (contraband); să se defalce adecă să se cosască; disenteria adecă inima rea; spre generație adecă spre prăsire; necesitatea adecă lipsa; necesitați sau strimtorați; proporția (potrivirea) etc. In these situations, the new terms are semantically explained by the author in order to make them more accessible, without creating an accurate semantic equivalence. Therefore, the equivalences established through glosses are not always precise, there appearing differences in the meanings of the lexical borrowing and the old term: suppressed or substituted semantic marks or semantic amplification. Many glosses of the same term are built through semantic completion, meaning restriction or extension, that shows that, many times, the glossing provides only the contextual meaning: acrimonia sau ascuțimea - acrimonia sau tăria, asprirea înrăotățită; cu afte adecă cu beșicuțe - aftele sau răniturile limbei; antifloghistice adecă asupra focului sau a aprinderei - antifloghistice adecă asupra fierbințelii; cautele adecă feriri - cautelele adecă luările aminte, apărările, scutirile contagiului; disenteria adecă inima rea, cea putredă - disenteria adecă cacăsînge, inima cea rea; înflamația sau aprinderea - inflămație (aprindere, obrintitură); periclu sau rișchiu adecă primejdia - rișchiu adecă primejdie; preservativ sau scutitoriu asupra pierzătoarei boală - preservativ adecă spre apărare, spreferire, spre scutire; preservativă sau apărare - spre preservativă sau apărare, scutire de vărsat - preservativă adecă apărare, scutire adeverită; prurit adecă mîncătură scărpinătoare - prurit adecă mîncare cu scărpinare; să se scarifacă adecă cu puțină impunsătură să se pleguiască sau rănească au cu cuțitul să se desfacă - să se scarifacă adecă lin să se străpungă; simptome adecă schimbări färă cumpăt - simptomele sau schimbările cele fără cumpăt ale morbului adecă a boalei - simptomele sau schimbările cele necumpătate ale boalei; să se trucidă adecă să se junghie - să se trucide sau să se împuşte - să-l trucizi adecă să-lomori etc.

3.4. There are, in the examined corpus, numerous glosses within which the lexical borrowings are equated with words belonging to the common lexicon, total or partial synonyms; these synonymic equivalences prove the rigorous scientific position of the Transylvanian scholar: amputația adecă tăierea; astremitatele adecă marginile, capetele, sfîrşiturile, lăturile; aversația adecă urîrea; cadabru adecă trupul cel mort; castrația adecă jugănirea; causa sau pricina; cornute adecă vite cu coarne; custodie (pază); damne adecă pagube; distanță (depărtare); diverse adecă deosebite; se devide sau se împarte; falsă adecă neadevăratăa fluid adecă curătoriu; genuin (adevărat); nude adecă goale; ocasia (prilejul); palatul adecă ceriul gurei; remediu (leac); respirația adecă răsuflarea; sapidă (plăcută); scabia adecă rîia; us adecă întrebuințare; veterinari sau doftori de vite etc.

\section{Conclusions}

With an obvious didactic character, the text examined highlights the explanatory and interpretative effort of the author who, in the process of forming the scientific language, had to face the lack of abstract concepts and terms; he was confronted with numerous and important problems of terminology, raised by the phase in which the Romanian of the period found itself: a language that was an imperfect and laborious work

\footnotetext{
${ }^{9}$ See, for this, Niculescu (1978, p. 154-155).
} 
instrument. Directly preoccupied with a more accessible reformulation of knowledge, P. Maior proves capable of realizing a compromise between the scientific accuracy and the readers' practical interests, between the neologic and the old, popular language. The gloss represents for him a device of inserting lexical borrowings, which are equated by synonyms or structures known by the reader. The overwhelming proportion of explanatory structures makes obvious the need of terminological clarification, the author assuring that the meaning of the new terms is understood by the reader. The high number of lexical terminological glosses, of the lexical borrowing - old term type shows that the scholar's main goal is the enrichment of the Romanian literary language and the creating of an erudite scientific terminology, an authentic profession he reaffirms in the postface of the writing: "Aceasta urmînd, nu numai limpede vei pricepe zisele cuvinte, ci şi noao cunoștință de multe cuvinte românești agonisindu-ți, înțelepțește vei îndemna, aprins de dragostea neamului tău, a îmbogăți dialecta patriei tale, precum toate neamurile Evropei astăzi se nevoiesc nu numai a-și curăți limba sa, a o netezi și a o polii, ci și la acea culme de deplinire a o înălța, cît să o facă de ajuns avută spre împărtăşirea tuturor științelor iubitorilor de învăţătură oamenilor săi; voind, dorind și suspinînd mama tuturor, natura, ca toți fiii săi, dintră carii pre români mai cu ales talant i-au avuțit și i-au înfrumsățat, cu toată vîrtutea să-și deplinească priceperea și voința spre mărirea lui Dumnezeu, făcătoriului său” (127-128). Therefore, the using of glosses aims at a wellestablished ideal: the formation of a cult, erudite literary lexicon in a period in which the formation of the scientific terminology in Romanian was stringent. In the case of glosses that render the concept through a periphrasis, which are clearly inferior, as number, to the terminological ones, the author's intent is that of informing and explaining (a tipical action of culturalization, enlightening) and not that of creating a terminological equivalent in Romanian.

\section{Bibliography}

Cuciureanu, Șt. (1959). Italienisme la Petru Maior, in “Studii și cercetări științifice”, Iași, X, fasc. 1-2, p. 53-67.

Duțu, Al. (1970). Traducere și remodelare în cultura română din perioada Luminilor, in Al. Dima (ed.), Probleme de literatură comparată și sociologie literară, Editura Academiei Romîne, București.

Gafton, Al. (2012). De la traducere la norma literară, Editura Universității “Alexandru Ioan Cuza”, Iași.

Maior, P. (1813). Istoria besericei românilor, Buda.

Niculescu, Al. (1978). Individualitatea limbii române între limbile romanice. 2. Contribuții socio-culturale, București.

Prodan, D. (1964). Preface to Gh. Șincai, Învățătură firească spre surparea superștiției norodului, critical edition and introductory study by D. Ghișe and P. Teodor, preface by D. Prodan, Editura Științifică, București.

Ursu, N. A. (1961). Cărți de popularizare a științei traduse de Petru Maior, in “Limba română”, X, no. 2, p. 135-143.

Ursu, N. A. (1962). Formarea terminologiei științifice românești, Editura Științifică, București.

Ursu, N. A. (2012). Alte două traduceri necunoscute ale lui Petru Maior, in “Limba română”, LXI, no. 3, p. 413-416. 